\title{
Pantoea vagans sp. nov., Pantoea eucalypti sp. nov., Pantoea deleyi sp. nov. and Pantoea anthophila sp. nov.
}

\author{
Carrie L. Brady, ${ }^{1}$ Stephanus N. Venter, ${ }^{1}$ Ilse Cleenwerck, ${ }^{2}$ \\ Katrien Engelbeen, ${ }^{2}$ Marc Vancanneyt, ${ }^{2}$ Jean Swings ${ }^{2}$ \\ and Teresa A. Coutinho ${ }^{1}$
}

Correspondence

Teresa A. Coutinho

teresa.coutinho@up.ac.za

\begin{abstract}
${ }^{1}$ Department of Microbiology and Plant Pathology, Forestry and Agricultural Biotechnology Institute (FABI), University of Pretoria, Pretoria 0002, South Africa
${ }^{2}$ BCCM/LMG Bacteria Collection, Ghent University, K. L. Ledeganckstraat 35, B-9000 Ghent, Belgium

The genus Pantoea was described to include several species belonging to the 'Erwinia herbicola-Enterobacter agglomerans' complex (Gavini et al., 1989). Presently, the genus comprises seven species with validly published names: Pantoea agglomerans and Pantoea dispersa (Gavini et al., 1989), Pantoea citrea, Pantoea punctata and Pantoea terrea (Kageyama et al., 1992) and Pantoea ananatis and Pantoea stewartii (Mergaert et al., 1993). Strains of Pantoea are diverse in their origin and geographical spread, and have been isolated from plants as well as from clinical samples.

Abbreviations: AFLP, amplified fragment length polymorphism; MLSA, multilocus sequence analysis.

The GenBank/EMBL/DDBJ accession numbers for the 16S rRNA gene sequences of $P$. eucalypti R-25678 (=LMG $24197^{\top}$ ), $P$. anthophila LMG $2558^{\top}$, P. deleyi R-31523 ${ }^{\top}\left(=\mathrm{LMG} 24200^{\top}\right)$ and $P$. vagans $\mathrm{R}-$ $21566^{\top}$ (=LMG 24199 ${ }^{\top}$ ) are EF688009-EF688012, respectively, and those of strains LMG 5345, LMG 5343, LMG 2781 and R-35496 are respectively EU216734-EU216737.

Detailed DNA-DNA hybridization results and a UPGMA dendrogram based on FAFLP analysis are available as supplementary material with the online version of this paper.
$P$. ananatis is the causal agent of bacterial blight and dieback of eucalyptus in South Africa (Coutinho et al., 2002). In 2001, Pantoea-like strains were isolated from eucalyptus trees exhibiting a similar disease in Uganda, Argentina and Uruguay and were thought to belong to $P$. ananatis. $P$. ananatis was also found to cause brown stalk rot of maize in South Africa (Goszczynska et al., 2007). Isolated simultaneously with $P$. ananatis from maize were additional Pantoea-like strains which also caused brown stalk rot. Multilocus sequence analysis (MLSA) has been shown to separate the isolates from eucalyptus and maize into three clusters, indicating that these strains probably constitute three novel species of Pantoea (Brady et al., 2008). Also included in the MLSA study were two strains, LMG 2558 (=NCPPB 1682) and LMG 2560 (=NCPPB 1941), mentioned by Beji et al. (1988) as belonging to protein profiling group VII, which were assigned to $P$. agglomerans based on their electrophoregrams, despite never being included in DNA-DNA hybridization experiments with the type strain of $P$. agglomerans. It was suggested by Gavini et al. (1989) that strains of protein 
Table 1. Strains used in this study

Abbreviations: LMG, BCCM/LMG Bacteria Collection, Ghent University, Belgium; BCC, Bacterial Culture Collection, Forestry and Agricultural Biotechnology Institute, Pretoria, South Africa; BD, Plant Pathogenic and Plant Protecting Bacteria (PPPPB) Culture Collection, ARC-PPRI, Pretoria, South Africa; CDC, Centers for Disease Control, Atlanta, GA, USA; NCPPB, National Collection of Plant Pathogenic Bacteria, York, UK.

\begin{tabular}{|c|c|c|}
\hline Strain & Source & Location \\
\hline \multicolumn{3}{|l|}{ Pantoea agglomerans (Br HG XIII)* } \\
\hline LMG $1286^{\mathrm{T}}$ & Clinical & Zimbabwe \\
\hline LMG 2565 & Cereal & Canada \\
\hline LMG 2596 & Onion & South Africa \\
\hline LMG 2660 & Wisteria floribunda & Japan \\
\hline \multicolumn{3}{|l|}{ Pantoea ananatis (Br HG VI)* } \\
\hline LMG $2665^{\mathrm{T}}$ & Pineapple & Brazil \\
\hline LMG 20103 & Eucalyptus & South Africa \\
\hline LMG 24190 & Onion & South Africa \\
\hline \multicolumn{3}{|l|}{ Pantoea stewartii subsp. stewartii } \\
\hline LMG $2715^{\mathrm{T}}$ & Maize & USA \\
\hline LMG 2718 & Maize & USA \\
\hline \multicolumn{3}{|l|}{ Pantoea stewartii subsp. indologenes } \\
\hline LMG $2632^{\mathrm{T}}$ & Fox millet & India \\
\hline LMG 2673 & Pineapple & Hawaii, USA \\
\hline \multicolumn{3}{|l|}{ Pantoea dispersa (Br HG III)* } \\
\hline LMG $2603^{\mathrm{T}}$ & Soil & Japan \\
\hline LMG 2602 & Sorghum & India \\
\hline LMG 2604 & Wild rose & Netherlands \\
\hline \multicolumn{3}{|l|}{ Pantoea citrea } \\
\hline LMG $22049^{\mathrm{T}}$ & Mandarin orange & Japan \\
\hline \multicolumn{3}{|l|}{ Pantoea punctata } \\
\hline LMG $22050^{\mathrm{T}}$ & Mandarin orange & Japan \\
\hline LMG 23562 & Mandarin orange & Japan \\
\hline \multicolumn{3}{|l|}{ Pantoea terrea } \\
\hline LMG $22051^{\mathrm{T}}$ & Soil & Japan \\
\hline LMG 23564 & Soil & Japan \\
\hline \multicolumn{3}{|c|}{ Pantoea anthophila sp. nov. (MLSA group C) } \\
\hline LMG $2558^{\mathrm{T}}=\mathrm{BD} 871^{\mathrm{T}}=\mathrm{NCPPB} 1682^{\mathrm{T}}$ & Impatiens balsamina & India \\
\hline LMG $2560=$ NCPPB 1941 & Tagetes erecta & Unknown \\
\hline \multicolumn{3}{|l|}{ Pantoea vagans sp. nov. (MLSA group A) } \\
\hline BCC $105^{\mathrm{T}}=\mathrm{LMG} 24199^{\mathrm{T}}=\mathrm{BD} 765^{\mathrm{T}}$ & Eucalyptus & Uganda \\
\hline BCC 013 =LMG 24195 & Eucalyptus & Uruguay \\
\hline BCC 015 =LMG 24196 & Eucalyptus & Argentina \\
\hline BD $639=$ LMG 24201 & Maize & South Africa \\
\hline BCC 081 & Eucalyptus & Uruguay \\
\hline BCC 072 & Eucalyptus & Uruguay \\
\hline BCC 208 & Eucalyptus & Uganda \\
\hline \multicolumn{3}{|l|}{ Pantoea eucalypti sp. nov. (MLSA group B) } \\
\hline BCC $076^{\mathrm{T}}=$ LMG $24197^{\mathrm{T}}=\mathrm{BD} 769^{\mathrm{T}}$ & Eucalyptus & Uruguay \\
\hline BCC 077 =LMG 24198 & Eucalyptus & Uruguay \\
\hline \multicolumn{3}{|l|}{ Pantoea deleyi sp. nov. (MLSA group D) } \\
\hline BCC $109^{\mathrm{T}}=\mathrm{LMG} 24200^{\mathrm{T}}=\mathrm{BD} 767^{\mathrm{T}}$ & Eucalyptus & Uganda \\
\hline \multicolumn{3}{|l|}{ Pantoea sp. (Br HG II, MLSA group H) } \\
\hline LMG $5345^{\mathrm{R}}=\mathrm{CDC} 3123-70^{\mathrm{R}} \dagger$ & Clinical & USA \\
\hline LMG $24526=$ CDC $238-70$ & Clinical & USA \\
\hline \multicolumn{3}{|l|}{ Pantoea sp. (Br HG IV, MLSA group I) } \\
\hline LMG $2781^{\mathrm{R}}=\mathrm{CDC} 1741-71^{\mathrm{R}} \dagger$ & Clinical & USA \\
\hline LMG $24529=$ CDC $3638-70$ & Clinical & USA \\
\hline \multicolumn{3}{|l|}{ Pantoea sp. (Br HG V, MLSA group E) } \\
\hline LMG $5343^{\mathrm{R}}=\mathrm{CDC} 3482-71^{\mathrm{R}_{\dagger}}$ & Clinical & USA \\
\hline LMG $24532=$ CDC 2928-68 & Clinical & USA \\
\hline \multicolumn{3}{|l|}{ Pantoea sp. (Br HG V, MLSA group F $)^{\star}$} \\
\hline LMG $24534^{\mathrm{R}}=$ CDC $3527-71^{\mathrm{R}_{\dagger}}$ & Clinical & USA \\
\hline
\end{tabular}


Table 1. cont.

$\dagger$ Reference strain.

${ }^{\star} \mathrm{Br} \mathrm{HG}$, Brenner hybridization group.

profiling group VII should be excluded from P. agglomerans, but that they should be included provisionally in Pantoea until their correct classification was determined. The MLSA results (Brady et al., 2008) indicated that strains LMG 2558 and LMG 2560 of Beji protein profiling group VII constitute another novel species belonging to Pantoea, as recommended by Gavini et al. (1989).

\section{Isolation of strains}

Isolates were obtained from eucalyptus leaves showing typical bacterial blight symptoms including leaf spots and watersoaked lesions. The leaves were surface-sterilized and crushed in sterile water and the resulting suspension was streaked on nutrient agar and incubated at $30{ }^{\circ} \mathrm{C}$ for 3 days. Single colonies were obtained by restreaking and incubation under the same conditions. Isolates from diseased maize plants were received from Dr T. Goszczynska (Plant Protection Research Institute, South Africa) (Goszczynska et al., 2007). Additional strains used in this study were obtained from the BCCM/ LMG Bacteria Collection (http://www.belspo.be/bccm) and the Centers for Disease Control, Atlanta, GA, USA. The strains used in this study are listed in Table 1.

\section{Amplified fragment length polymorphism (AFLP) analysis}

Genomic DNA was extracted from all strains using the DNeasy Tissue kit (Qiagen). AFLP analysis was performed according to the method described previously (Brady et al., 2007) using the selective primer combination Eco-C/MseGC. Band patterns were analysed with BioNumerics 4.0 (Applied Maths) and compared with a database containing profiles of reference strains of all Pantoea species with validly published names. A UPGMA dendrogram was constructed using Pearson's correlation coefficient. The isolates from eucalyptus and maize were divided into three clusters by AFLP analysis and the two strains from the study of Beji et al. (1988) formed a separate cluster (see Supplementary Fig. S1, available in IJSEM Online). These AFLP clusters did not contain any reference strains, suggesting that the strains belonged to novel species.

\section{$16 S$ rRNA gene sequencing}

Almost-complete 16S rRNA gene sequences were determined for selected strains from each AFLP cluster using the primers and conditions described by Coenye et al. (1999). The sequences were aligned using CLUSTAL_x (Thompson et al., 1997) and overhangs were trimmed. The program MODELTEST 3.7 (Posada \& Crandall, 1998) was then applied to the datasets to determine the best-fit evolutionary model. Maximum-likelihood and neighbour-joining analyses were performed using Phyml (Guindon \& Gascuel, 2003) and PAUP 4.0b10 (Swofford, 2000), respectively, by applying the models and parameters determined by MODELTEST (only maximum-likelihood phylogenetic trees are shown). Bootstrap analysis with 1000 replicates was performed on the trees to assess the reliability of the clusters. The $16 \mathrm{~S}$ rRNA gene sequence similarity of strains of the four novel species was greater than $98 \%$ to $P$. agglomerans, $P$. ananatis, $P$. stewartii and $P$. dispersa. In the $16 \mathrm{~S}$ rRNA gene phylogenetic tree, the four novel species cluster within the Pantoea 'core' group, each on a separate branch, along with $P$. agglomerans, $P$. stewartii and $P$. ananatis (Fig. 1). The bootstrap support within the Pantoea cluster was generally quite low, although this can be explained by the high level of homoplasy in the 16S rRNA gene sequences of members of the Enterobacteriaceae (Stephan et al., 2007). Pantoea has also been shown to be polyphyletic, making it difficult to resolve taxonomic issues within the genus (Brady et al., 2008).

\section{gyrB, rpoB, atpD and infB sequences}

In order to provide stronger support for the description of the four novel Pantoea species, MLSA based on gyrB, rpoB, atpD and $\operatorname{infB}$ gene sequences was performed on the strains (Brady et al., 2008). Sequence analysis and tree construction was performed as described above. MLSA revealed that the isolates from eucalyptus and maize and the strains from Beji protein profiling group VII form four wellsupported clusters in the concatenated tree (Fig. 2), which were referred to as MLSA groups A, B, C and D (Brady et al., 2008). The four novel species could also be differentiated clearly from Brenner's hybridization groups II, IV and V (Brenner et al., 1984), referred to as MLSA groups E, F, H and I in the Pantoea MLSA study (Brady et al., 2008) (Figs 1 and 2) and belonging to Pantoea according to Grimont \& Grimont (2005).

\section{DNA-DNA hybridizations}

High-quality DNA for DNA-DNA hybridization was prepared by the method of Wilson (1987), with minor modifications (Cleenwerck et al., 2002). DNA-DNA hybridizations were performed using the microplate method (Ezaki et al., 1989) with some modifications (Cleenwerck et al., 2002). The hybridization temperature was $45 \pm 1{ }^{\circ} \mathrm{C}$. Reciprocal reactions $(\mathrm{A} \times \mathrm{B}$ and $\mathrm{B} \times \mathrm{A})$ were performed for every DNA pair from all strains and their variation was within the limits of this method (Goris et al., 1998). The values presented are based on a minimum of four replicates. Representative strains from MLSA groups 
A, B, C and D were selected and hybridized to the type strains of $P$. agglomerans (LMG $1286^{\mathrm{T}}$ ), P. ananatis (LMG $\left.2665^{\mathrm{T}}\right), P$. stewartii (LMG $2715^{\mathrm{T}}$ ) and $P$. dispersa (LMG 2603 ${ }^{\mathrm{T}}$ ) and among each other. DNA-DNA hybridization was also performed with strains from other species of the genus Pantoea with validly published names as well as with strains of Brenner's hybridization groups II, IV and V. These results are available in Supplementary Table S1. The level of DNADNA binding between representative strains of MLSA groups A-D and the type strain of $P$. agglomerans was less than $68 \%$, less than $30 \%$ to the type strains of $P$. ananatis and $P$. dispersa and less than $15 \%$ to the type strain of $P$. stewartii. The strains of MLSA groups A-D exhibited less than $44 \%$ DNA relatedness when hybridized to strains from Brenner's hybridization groups II, IV and V. When seven strains from MLSA group A, isolated from eucalyptus and maize, were hybridized with each other (LMG $24199^{\mathrm{T}}$, LMG 24195, LMG 24196, LMG 24201, BCC 072, BCC 081 and BCC 427), they exhibited levels of DNA relatedness ranging from 83 to $103 \%$ (data presented in part in Supplementary Table S1). The hybridization values between strains LMG $24197^{\mathrm{T}}$ and LMG 24198 (MLSA group B), also isolated from eucalyptus, and LMG $2558^{\mathrm{T}}$ and LMG 2560 (MLSA group C) were even higher, at 99 and $105 \%$, respectively.

\section{DNA $\mathbf{G}+\mathbf{C}$ content}

The ranges of $\mathrm{G}+\mathrm{C}$ content of DNA of the four novel species, determined by HPLC (Mesbah et al., 1989), are as

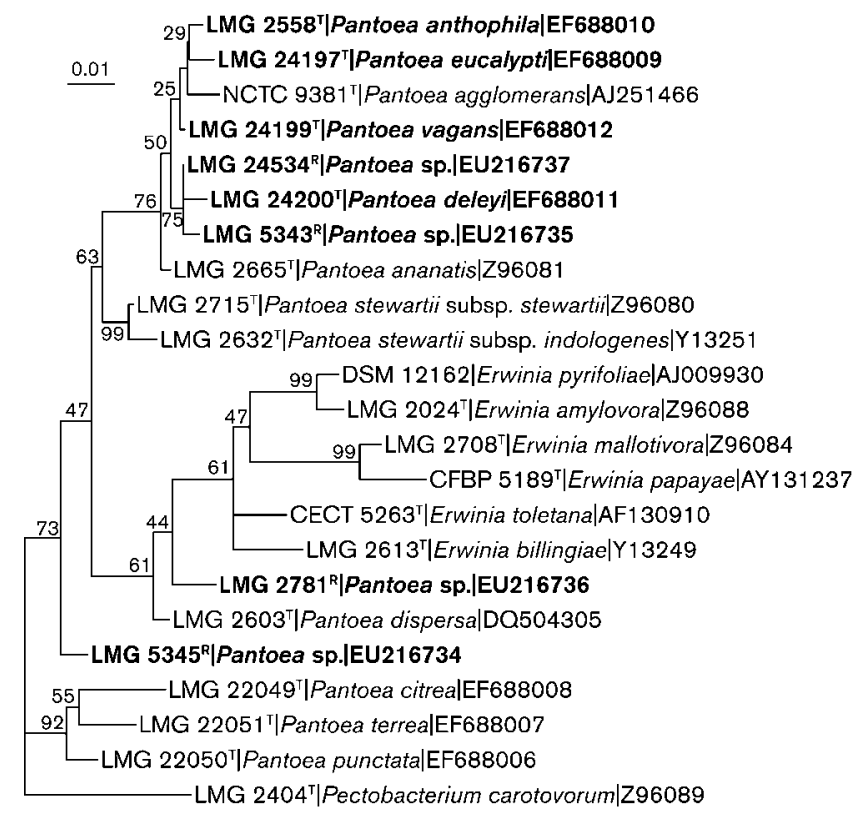

Fig. 1. Maximum-likelihood tree based on 16S rRNA gene sequences of Pantoea strains. Bootstrap values after 1000 replicates are expressed as percentages. The sequence of Pectobacterium carotovorum LMG $2404^{\top}$ was included as an outgroup. Bar, fraction of substitutions per site. follows: MLSA group A (LMG 24199 ${ }^{\mathrm{T}}$, LMG 24195, LMG 24196, LMG 24201, BCC 072, BCC 081 and BCC 427), 55.2-55.8 mol\%; MLSA group B (LMG $24197^{\mathrm{T}}$ and LMG 24198), 54.3-54.5 mol\%; MLSA group D (LMG $24200^{\mathrm{T}}$ ), $58.6 \mathrm{~mol} \%$; and MLSA group C (LMG $2558^{\mathrm{T}}$ and LMG 2560), 57.4-57.5 mol\%.

\section{Phenotypic assays}

Physiological and biochemical tests were performed on selected isolates using API 20E, API 50CHB/E and Biotype100 strips (bioMérieux) as well as Biolog GN plates. The samples were observed for 6 days, although the majority of reactions occurred after 3 days. Results are given in the species descriptions. The four novel species can be differentiated from their closest phylogenetic neighbours by their ability to utilize L-ornithine (differentiation from $P$. agglomerans, $P$. ananatis, $P$. dispersa and $P$. stewartii), Tweens 40 and 80 (differentiation from $P$. agglomerans, $P$. ananatis and $P$. dispersa) and L-tartrate (differentiation from $P$. agglomerans, $P$. stewartii and P. anthophila) and by their inability to utilize lactose (differentiation from $P$. ananatis, $P$. dispersa, $P$. stewartii and $P$. eucalypti). The following characteristics can be used to differentiate the four novel species from each other: utilization of D-

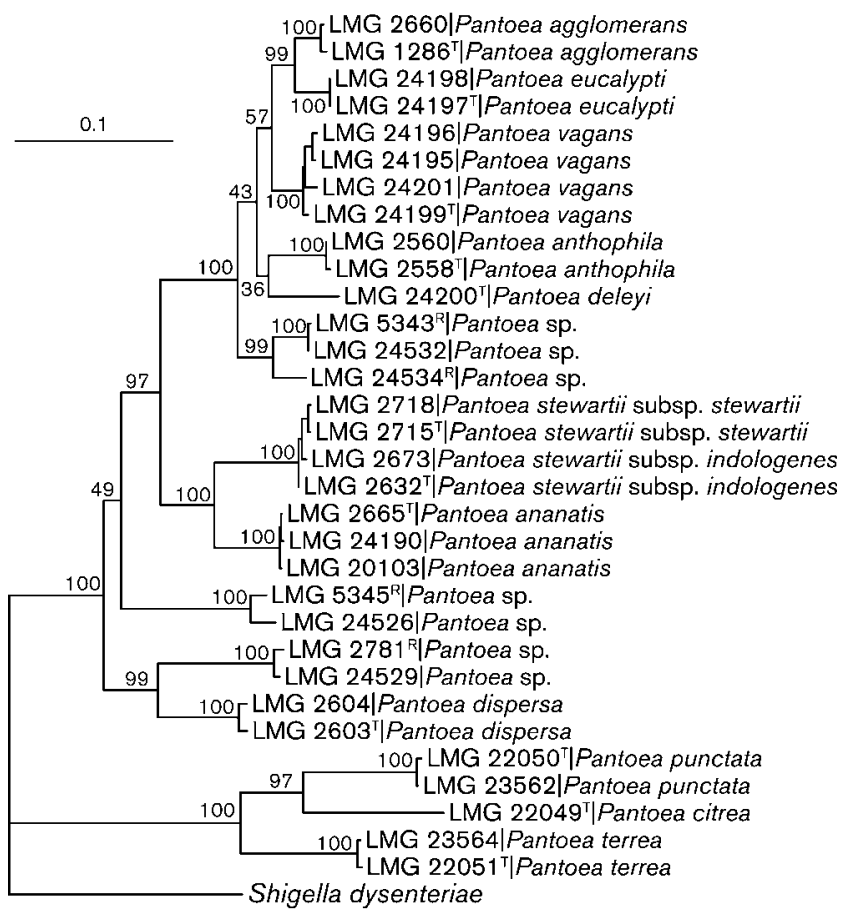

Fig. 2. Maximum-likelihood tree based on concatenated gyrB, $r p o B$, atp $D$ and infB sequences of selected Pantoea strains. Bootstrap values after 1000 replicates are expressed as percentages. Sequences from Shigella dysenteriae M131649 were obtained from the genome sequencing database of the Sanger Institute (http://www.sanger.ac.uk) and included as an outgroup. Bar, fraction of substitutions per site. 
arabitol, gentiobiose, 5-ketogluconate, lactose, malonic acid and L-pyroglutamic acid. A summary of the most distinguishing phenotypic characteristics from the Biotype100 and Biolog systems, which can differentiate the four novel species from their closest phylogenetic neighbours and each other, is presented in Table 2 .

\section{Conclusions}

The data presented in this study indicate that the strains isolated from eucalyptus and maize and the strains from protein profiling group IV (Beji et al., 1988) form four distinct genetic groups. These genetic groups are supported by AFLP, nucleotide sequence analysis and DNA-DNA hybridization values. The DNA-DNA relatedness between strains of $P$. agglomerans and MLSA group A (Pantoea vagans sp. nov.) may be considered borderline, as the values are just below the recommended species demarcation of $70 \%$ (Wayne et al., 1987). However, both $16 \mathrm{~S}$ rRNA gene sequencing and MLSA support the phylogenetic delineation of $P$. vagans from $P$. agglomerans. Past studies have highlighted the difficulties in identifying Pantoea strains based on phenotypic data (Beji et al., 1988; Brenner et al., 1984; Mergaert et al., 1984; Verdonck et al., 1987), and it has been suggested that caution be exercised when basing identification solely on commercial phenotypic identification systems (Gavini et al., 1989). Despite the high phenotypic similarity within the genus Pantoea, several biochemical characteristics were recognized that could distinguish the four novel species from each other and from their closest phylogenetic neighbours. Therefore, we propose to classify the four novel species identified in this study as Pantoea vagans sp. nov. (MLSA group A) for strains isolated from eucalyptus and maize, Pantoea eucalypti sp. nov. (MLSA group B) for strains isolated from eucalyptus in Uruguay, Pantoea deleyi sp. nov. (MLSA group D) for the strain isolated from eucalyptus in Uganda and Pantoea anthophila sp. nov. (MLSA group C) for the two strains belonging to Beji protein profiling group VII (Brady et al., 2008).

\section{Description of Pantoea vagans sp. nov.}

Pantoea vagans (va'gans. L. part. adj. vagans roaming, referring to the wide distribution of the species).

Cells are Gram-negative, short rods $(0.9 \times 1.5-3.0 \mu \mathrm{m})$ occurring singly or in pairs, motile and non-sporeforming. Colonies are beige to yellow, round, convex and smooth with entire margins. Facultatively anaerobic and oxidase-negative. Acetoin and $\beta$-galactosidase are produced. Indole, $\mathrm{H}_{2} \mathrm{~S}$ and urease are not produced. Acid is produced from L-arabinose, D-ribose, D-xylose, L-rhamnose, inositol, D-mannitol, $\mathrm{N}$-acetylglucosamine, lactose (weak), sucrose, D-lyxose and D-fucose. The following carbon sources are utilized at $28{ }^{\circ} \mathrm{C}$ within 3-6 days: Larabinose, D-ribose, D-xylose, D-galactose, D-glucose, Dfructose, D-mannose, maltotriose, L-rhamnose, inositol, aesculin, D-mannitol, maltose, trehalose, cellobiose, sucrose, glycerol, L-tartrate, succinate, fumarate, L-aspartate, L-glutamate, cis- and trans-aconitate, L-proline, D- and L-alanine, L-serine, malonic acid, Tweens 40 and 80 , D-lyxose (weak), gentiobiose (weak) and citric acid (weak). The following carbon sources are not utilized at $28{ }^{\circ} \mathrm{C}$ within 3-6 days: erythritol, D-adonitol, L-sorbose, dulcitol, D-sorbitol, amygdalin, inulin, raffinose, lactose, lactulose, glycogen, xylitol, turanose, D-tagatose, L-arabitol, 2-ketoglutarate, 5-ketogluconate, L-fucose, 3-O-methyl-D-glucopyranose, D-tartrate, L-tryptophan, L-histidine, glutarate, malonate, propionate and L-tyrosine. The $\mathrm{G}+\mathrm{C}$ content of the type strain is $55.4 \mathrm{~mol} \%$.

Table 2. Characteristics that distinguish the novel species from each other and from their closest phylogenetic neighbours

Species/subspecies: 1, P. agglomerans (3 strains); 2, P. ananatis (4); 3, P. dispersa (1); 4, P. stewartii subsp. stewartii (1); 5, P. stewartii subsp. indologenes (1); 6, P. vagans sp. nov. (7); 7, P. eucalypti sp. nov. (2); 8, P. deleyi sp. nov. (1); 9, P. anthophila sp. nov. (2). +, 90-100\% of strains positive in 3-6 days; $(+)$, weakly positive;,$- 90-100 \%$ of strains negative; ND, not determined. Additional phenotypic data were obtained from Grimont \& Grimont (2005).

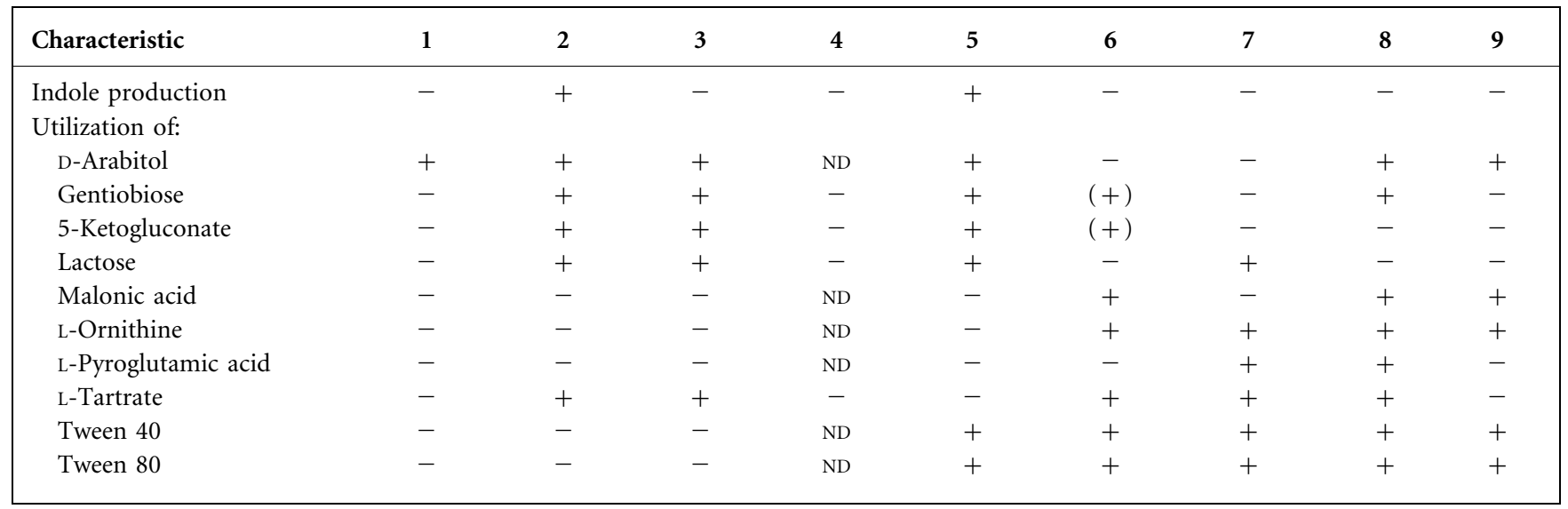


The type strain is R-21566 ${ }^{\mathrm{T}}\left(=\mathrm{LMG} 24199^{\mathrm{T}}=\mathrm{BCC} 105^{\mathrm{T}}\right.$ $=\mathrm{BD} 765^{\mathrm{T}}$ ), isolated from eucalyptus in Uganda. Strains belonging to this species have been isolated from eucalyptus leaves showing symptoms of bacterial blight and die-back in Uganda, Uruguay and Argentina and from maize suffering from brown stalk rot in South Africa.

\section{Description of Pantoea eucalypti sp. nov.}

Pantoea eucalypti (eu.ca.lyp'ti. N.L. gen. n. eucalypti of Eucalyptus, referring to the host from which the first strains where isolated).

Cells are Gram-negative, short rods $(0.9 \times 1.5-3.0 \mu \mathrm{m})$ occurring singly or in pairs, motile and non-spore-forming. Colonies are beige to yellow with a darker centre, round, convex and smooth with entire margins. Facultatively anaerobic and oxidase-negative. Acetoin and $\beta$-galactosidase are produced. Indole, $\mathrm{H}_{2} \mathrm{~S}$ and urease are not produced. Acid is produced from L-arabinose, D-ribose, D-xylose, L-rhamnose, inositol, D-mannitol, $\mathrm{N}$-acetylglucosamine, lactose and sucrose. The following carbon sources are utilized at $28{ }^{\circ} \mathrm{C}$ within 3-6 days: L-arabinose, D-ribose, D-xylose, D-galactose, D-glucose, D-fructose, D-mannose, maltotriose, L-rhamnose, inositol, aesculin, D-mannitol, maltose, trehalose, cellobiose, lactose, sucrose, glycerol, L-pyroglutamic acid, L-tartrate, succinate, fumarate, L-aspartate, L-glutamate, cis- and transaconitate, L-proline, D- and L-alanine, L-serine, Tweens 40 and 80 and citric acid. The following carbon sources are not utilized at $28{ }^{\circ} \mathrm{C}$ within 3-6 days: erythritol, D-adonitol, Lsorbose, dulcitol, D-sorbitol, amygdalin, inulin, raffinose, lactulose, glycogen, xylitol, turanose, D-tagatose, L-arabitol, 2-ketoglutarate, 5-ketogluconate, L-fucose, 3-O-methyl-Dglucopyranose, D-tartrate, L-tryptophan, L-histidine, glutarate, malonate, propionate, L-tyrosine, gentiobiose and malonic acid. The $\mathrm{G}+\mathrm{C}$ content of the type strain is $54.5 \mathrm{~mol} \%$.

The type strain is $\mathrm{R}-25678^{\mathrm{T}}\left(=\mathrm{LMG} 24197^{\mathrm{T}}=\mathrm{BCC} 076^{\mathrm{T}}\right.$ $=\mathrm{BD} 769^{\mathrm{T}}$ ), isolated from eucalyptus in Uruguay. Strains belonging to this species have been isolated from eucalyptus leaves showing symptoms of bacterial blight and die-back in Uruguay.

\section{Description of Pantoea deleyi sp. nov.}

Pantoea deleyi (de.ley'i. N.L. masc. gen. n. deleyi of De Ley, named for Jozef De Ley, who contributed to the formation of the genus Pantoea).

Cells are Gram-negative, short rods $(0.9 \times 1.5-3.0 \mu \mathrm{m})$ occurring singly or in pairs, motile and non-sporeforming. Colonies are beige to yellow, round, convex and smooth with entire margins. Facultatively anaerobic and oxidase-negative. Acetoin and $\beta$-galactosidase are produced. Indole, $\mathrm{H}_{2} \mathrm{~S}$ and urease are not produced. Acid is produced from D- and L-arabinose, D-ribose, D-xylose, Lrhamnose, D-mannitol, $\mathrm{N}$-acetylglucosamine, gentiobiose, sucrose, D-lyxose, D-fucose and D-arabitol. The following carbon sources are utilized at $28{ }^{\circ} \mathrm{C}$ within 3-6 days: $\mathrm{L}-$ arabinose, D-ribose, D-xylose, D-galactose, D-glucose, Dfructose, D-mannose, maltotriose, L-rhamnose, aesculin, D-mannitol, turanose, maltose, trehalose, sucrose, glycerol, L-pyroglutamic acid, inositol, succinate, fumarate, L-aspartate, L-glutamate, L-tartrate, cis- and trans-aconitate, L-proline, D- and L-alanine, L-serine, malonic acid, Tweens 40 and 80, D-lyxose, D-arabitol, gentiobiose and citric acid. The following carbon sources are not utilized at $28{ }^{\circ} \mathrm{C}$ within 3-6 days: erythritol, D-adonitol, cellobiose, lactose, lactulose, L-sorbose, dulcitol, D-sorbitol, amygdalin, inulin, raffinose, glycogen, xylitol, D-tagatose, L-arabitol, gluconate, 2-ketoglutarate, 5-ketogluconate, Lfucose, 3-O-methyl-D-glucopyranose, D-tartrate, L-tryptophan, L-histidine, glutarate, malonate, propionate and $\mathrm{L}$-tyrosine. The $\mathrm{G}+\mathrm{C}$ content of the type strain is $58.6 \mathrm{~mol} \%$.

The type strain is $\mathrm{R}-31523^{\mathrm{T}}\left(=\mathrm{LMG} 24200^{\mathrm{T}}=\mathrm{BCC} 109^{\mathrm{T}}\right.$ $=\mathrm{BD} 767^{\mathrm{T}}$ ), isolated from eucalyptus leaves showing symptoms of bacterial blight and die-back in Uganda.

\section{Description of Pantoea anthophila sp. nov.}

Pantoea anthophila (an.tho' phi.la. Gr. n. anthos flower; Gr. adj. philos loving; N.L. fem. adj. anthophila flower-loving, pertaining to the source of isolation of known strains).

Cells are Gram-negative, short rods $(0.9 \times 1.2-2.5 \mu \mathrm{m})$ occurring singly or in pairs, motile and non-sporeforming. Colonies are beige to yellow, round, convex and smooth with entire margins. Facultatively anaerobic and oxidase-negative. Acetoin and $\beta$-galactosidase are produced. Indole, $\mathrm{H}_{2} \mathrm{~S}$ and urease are not produced. Acid is produced from L-arabinose, D-ribose, D-xylose, L-rhamnose, inositol, D-mannitol, $\mathrm{N}$-acetylglucosamine, sucrose and D-arabitol. The following carbon sources are utilized at $28{ }^{\circ} \mathrm{C}$ within 3-6 days: L-arabinose, D-ribose, D-xylose, Dgalactose, D-glucose, D-fructose, D-mannose, maltotriose, L-rhamnose, inositol, aesculin, glycogen, D-lyxose, Dmannitol, maltose, trehalose, cellobiose, sucrose, glycerol, succinate, fumarate, L-aspartate, L-glutamate, cis- and trans-aconitate, L-proline, D- and L-alanine, L-serine, malonic acid, Tweens 40 and 80 and citric acid. The following carbon sources are not utilized at $28{ }^{\circ} \mathrm{C}$ within 36 days: erythritol, D-adonitol, L-sorbose, dulcitol, D-sorbitol, amygdalin, inulin, raffinose, lactose, lactulose, xylitol, turanose, D-tagatose, L-arabitol, L-tartrate, 2-ketoglutarate, 5-ketogluconate, L-fucose, 3-O-methyl-D-glucopyranose, D-tartrate, L-tryptophan, L-histidine, glutarate, malonate, propionate, gentiobiose and L-tyrosine. The $\mathrm{G}+\mathrm{C}$ content of the type strain is $57.5 \mathrm{~mol} \%$.

The type strain is LMG $2558^{\mathrm{T}}\left(=\mathrm{BD} 871^{\mathrm{T}}=\mathrm{NCPPB}\right.$ $1682^{\mathrm{T}}$ ), isolated from Impatiens balsamina in India. Strains belonging to this species have been isolated from flowering shrubs. 


\section{Acknowledgements}

This study was partially supported by the South African-Flemish Bilateral Agreement, the National Research Foundation (NRF), the Tree Protection Co-operative Programme (TPCP) and the THRIP support programme of the Department of Trade and Industry, South Africa. The BCCM/LMG Bacteria collection is supported by the Federal Public Planning Service-Science Policy, Belgium. The authors wish to acknowledge Katrien Vandemeulebroecke for technical assistance, Mike Wingfield, Teresa Goszczynska, Jolanda Roux, Grace Nakabonge and Izette Greyling for allowing us to include several strains isolated from Eucalyptus, onion and maize in the study and Mrs Mohr for providing us with the CDC strains.

\section{References}

Beji, A., Mergaert, J., Gavini, F., Izard, D., Kersters, K., Leclerc, H. \& De Ley, J. (1988). Subjective synonymy of Erwinia herbicola, Erwinia milletiae, and Enterobacter agglomerans and redefinition of the taxon by genotypic and phenotypic data. Int J Syst Bacteriol 38, 77-88.

Brady, C. L., Venter, S. N., Cleenwerck, I., Vancanneyt, M., Swings, J. \& Coutinho, T. A. (2007). A FAFLP system for the improved identification of plant-pathogenic and plant-associated species of the genus Pantoea. Syst Appl Microbiol 30, 413-417.

Brady, C. L., Cleenwerck, I., Venter, S. N., Vancanneyt, M., Swings, J. \& Coutinho, T. A. (2008). Phylogeny and identification of Pantoea species associated with plants, humans and the natural environment based on multilocus sequence analysis (MLSA). Syst Appl Microbiol 31, 447-460.

Brenner, D. J., Fanning, G. R., Leete Knutson, J. K., Steigerwalt, A. G. \& Krichevsky, M. I. (1984). Attempts to classify herbicola groupEnterobacter agglomerans strains by deoxyribonucleic acid hybridization and phenotypic tests. Int J Syst Bacteriol 34, 45-55.

Cleenwerck, I., Vandemeulebroecke, K., Janssens, D. \& Swings, J. (2002). Re-examination of the genus Acetobacter, with descriptions of Acetobacter cerevisiae sp. nov. and Acetobacter malorum sp. nov. Int $J$ Syst Evol Microbiol 52, 1551-1558.

Coenye, T., Falsen, E., Vancanneyt, M., Hoste, B., Govan, J. R. W., Kersters, K. \& Vandamme, P. (1999). Classification of Alcaligenes faecalis-like isolates from the environment and human clinical samples as Ralstonia gilardii sp. nov. Int J Syst Bacteriol 49, 405-413.

Coutinho, T. A., Preisig, O., Mergaert, J., Cnockaert, M. C., Riedel, K. H., Swings, J. \& Wingfield, M. J. (2002). Bacterial blight and dieback of Eucalyptus species, hybrids and clones in South Africa. Plant Dis 86, 20-25.

Ezaki, T., Hashimoto, Y. \& Yabuuchi, E. (1989). Fluorometric deoxyribonucleic acid-deoxyribonucleic acid hybridization in microdilution wells as an alternative to membrane filter hybridization in which radioisotopes are used to determine genetic relatedness among bacterial strains. Int J Syst Bacteriol 39, 224-229.

Gavini, F., Mergaert, J., Beji, A., Mielcarek, C., Izard, D., Kersters, K. \& De Ley, J. (1989). Transfer of Enterobacter agglomerans (Beijerinck 1988) Ewing and Fife 1972 to Pantoea gen. nov. as Pantoea agglomerans comb. nov. and description of Pantoea dispersa sp. nov. Int J Syst Bacteriol 39, 337-345.
Goris, J., Suzuki, K., De Vos, P., Nakase, T. \& Kersters, K. (1998). Evaluation of a microplate DNA-DNA hybridization method compared with the initial renaturation method. Can J Microbiol 44, 1148-1153.

Goszczynska, T., Botha, W. J., Venter, S. N. \& Coutinho, T. A. (2007). Isolation and identification of the causal agent of brown stalk rot, a new disease of maize in South Africa. Plant Dis 91, 711-718.

Grimont, P. A. D. \& Grimont, F. (2005). Genus XXIII. Pantoea Gavini, Mergaert, Beji, Mielcarek, Izard, Kersters and De Ley 1989b, $343^{\mathrm{VP}}$. In Bergey's Manual of Systematic Bacteriology, 2nd edn, vol. 2, part B, pp. 713-720. Edited by D. J. Brenner, N. R. Krieg, J. T. Staley \& G. M. Garrity. New York: Springer.

Guindon, S. \& Gascuel, O. (2003). A simple, fast, and accurate algorithm to estimate large phylogenies by maximum likelihood. Syst Biol 52, 696-704.

Kageyama, B., Nakae, M., Yagi, S. \& Sonoyama, T. (1992). Pantoea punctata sp. nov., Pantoea citrea sp. nov., and Pantoea terrea sp. nov. isolated from fruit and soil samples. Int J Syst Bacteriol 42, 203-210.

Mergaert, J., Verdonck, L., Kersters, K., Swings, J., Boeufgras, J.-M. \& De Ley, J. (1984). Numerical taxonomy of Erwinia species using API systems. J Gen Microbiol 130, 1893-1910.

Mergaert, J., Verdonck, L. \& Kersters, K. (1993). Transfer of Erwinia ananas (synonym, Erwinia uredovora) and Erwinia stewartii to the genus Pantoea emend. as Pantoea ananas (Serrano 1928) comb. nov. and Pantoea stewartii (Smith 1898) comb. nov., respectively, and description of Pantoea stewartii subsp. indologenes subsp. nov. Int J Syst Bacteriol 43, 162-173.

Mesbah, M., Premachandran, U. \& Whitman, W. B. (1989). Precise measurement of the $\mathrm{G}+\mathrm{C}$ content of deoxyribonucleic acid by highperformance liquid chromatography. Int J Syst Bacteriol 39, 159-167.

Posada, D. \& Crandall, K. A. (1998). Modeltest: testing the model of DNA substitution. Bioinformatics 14, 817-818.

Stephan, R., Van Trappen, S., Cleenwerck, I., Vancanneyt, M., De Vos, P. \& Lehner, A. (2007). Enterobacter turicensis sp. nov. and Enterobacter helveticus sp. nov., isolated from fruit powder. Int J Syst Evol Microbiol 57, 820-826.

Swofford, D. L. (2000). PAUP ${ }^{*}$ : phylogenetic analysis using parsimony and other methods. Sunderland, MA: Sinauer Associates.

Thompson, J. D., Gibson, T. J., Plewniak, F., Jeanmougin, F. \& Higgins, D. G. (1997). The CLUSTAL_X windows interface: flexible strategies for multiple sequence alignment aided by quality analysis tools. Nucleic Acids Res 25, 4876-4882.

Verdonck, L., Mergaert, J., Rijckaert, C., Swings, J., Kersters, K. \& De Ley, J. (1987). Genus Erwinia: numerical analysis of phenotypic features. Int J Syst Bacteriol 37, 4-18.

Wayne, L. G., Brenner, D. J., Colwell, R. R., Grimont, P. A. D., Kandler, O., Krichevsky, M. I., Moore, L. H., Moore, W. E. C., Murray, R. G. E. \& other authors (1987). International Committee on Systematic Bacteriology. Report of the ad hoc committee on reconciliation of approaches to bacterial systematics. Int J Syst Bacteriol 37, 463-464.

Wilson, K. (1987). Preparation of genomic DNA from bacteria. In Current Protocols in Molecular Biology, pp. 2.4.1-2.4.5. Edited by F. M. Ausubel, R. Brent, R. E. Kingston, D. D. Moore, J. G. Seidman, J. A. Smith \& K. Struhl. New York: Green Publishing \& Wiley-Interscience. 